\title{
MICROSATELLITE DNA-BASED GENETIC TRACEABILITY OF TWO POPULATIONS OF SPLENDID ALFONSINO, BERYX SPLENDENS (ACTINOPTERYGII: BERYCIFORMES: BERYCIDAE)-PROJECT CELFISH-PART 2
}

\author{
Jolanta KEMPTER*, Maciej KIEŁPIŃSKI, Remigiusz PANICZ, and Sławomir KESZKA \\ Division of Aquaculture, West Pomeranian University of Technology, Szczecin, Kazimierza Krolewicza 4, \\ 71-550 Szczecin, Poland
}

\begin{abstract}
Kempter J., Kiełpinski M., Panicz R., Keszka S. 2016. Microsatellite DNA-based genetic traceability of two populations of splendid alfonsino, Beryx splendens (Actinopterygii: Beryciformes: Berycidae) Project CELFISH—Part 2. Acta Ichthyol. Piscat. 46 (4): 287-291.
\end{abstract}

\begin{abstract}
Background. The study is a contribution to Project CELFISH which involves genetic identification of populations of fish species presenting a particular economic importance or having a potential to be used in the so-called commercial substitutions. The EU fish trade has been showing a distinct trend of more and more fish species previously unknown to consumers being placed on the market. Molecular assays have become the only way with which to verify the reliability of exporters. This paper is aimed at pinpointing genetic markers with which to label and differentiate between two populations of splendid alfonsino, Beryx splendens Lowe, 1834, a species highly attractive to consumers in Asia and Oceania due to the meat taste and low fat content.

Material and methods. DNA was isolated from fragments of fins collected at local markets in Japan (MJ) $(n=$ $10)$ and New Zealand (MNZ) $(n=18)$. The rhodopsin gene (RH1) fragment and 16 microsatellite DNA fragments (SSR) were analysed in all the individuals. The sequences obtained were processed using the BioEdit and BLAST software, whereas SSR data were processed with the GeAlEX analysis package.

Results. The BioEdit software-aided comparison of MJ and MNZ nucleotide sequences of the rhodopsin gene fragments were identical and showed $100 \%$ agreement with the alfonsino sequence deposited under access number DQ197832. The preliminary analysis of SSR markers showed all the loci analysed in both populations to be polymorphic, and when randomly selected specimens were assigned to the original populations. The affinity test correctly identified the provenance of all those specimens.

Conclusion. The results obtained constitute a tool for molecular differentiation between alfonsino populations collected in the FAO 81 (New Zealand) and FAO 71 (Japan) areas for the purpose of catch quota control and for checking the agreement between the label declaration and the actual product.
\end{abstract}

Keywords: conservation genetics, marine resources, seafood authentication, seafood counterfeiting

\section{INTRODUCTION}

As consumers in the developed countries require accurate information on the goods available on the market, detection of food counterfeiting has become an increasingly important issue. The issue is particularly relevant to fish and shellfish as it is difficult to authenticate products of fisheries and aquaculture. In many cases, there are no methods with which to efficiently verify the identity of such products. Consumers are increasingly frequently prone to select goods of 'certified origin' and do not wish to purchase fish from illegal catches. Environmental issues affect those choices as well. Today's consumers require information whether the open sea products available on the market have been harvested without harming populations, causing overfishing through selection of inappropriate sizes, or fishing the species regarded by IUCN as threatened. According to Johnson (2014), fish and shellfish counterfeiting primarily involves substitution of valuable species by less nutritionally beneficial ones which in turn may be a source of gastric infections or unexpected allergies. The latter are particularly dangerous for children and seniors as well as for individuals on diets that exclude consumption of certain types of animal fat and/or protein. In such cases, food counterfeiting poses a health danger and should not be tolerated.

During three years (2011-2013), the West Pomeranian University of Technology in Szczecin (Poland) has been involved in a research carried out within the framework of the Project CELFISH ("Development of a genetic-based system for identification of food products form fisheries

\footnotetext{
* Correspondence: Dr. hab. Jolanta Kempter, Zakład Akwakultury, Wydział Nauk o Żywności i Rybactwa, Zachodniopomorski Uniwersytet Technologiczny w Szczecinie, ul. Kazimierza Królewicza 4, 71-550 Szczecin, phone: +48 91449 6663, e-mail: (JK) jkempter@zut.edu.pl, (MK) mkielpinski@zut.edu.pl, (RP) rpanicz@zut.edu.pl, (SK) skeszka@zut.edu.pl.
} 
and aquaculture introduced to the European Union customs area") (See Part 1 of this project contribution at DOI: 10.3750/AIP2014.44.2.08). The project participants have collected about 12000 samples of fish from several countries worldwide which contribute most to the European Union seafood imports. The molecular assays performed are meant to provide the customs and food inspection services with a DNA-based tool with which to identify not only a fish species, but a population and the capture site. The project will deliver a genetic data base, the development of which is in progress. The data base will cover about 300 fish species from waters off all the continents. Genetic traceability of fish products as well as population identification using molecular methods provide useful information about the catch region and is important for developing conservation plans for overfished populations or catches from IUU (Illegal, Unreported, and Unregulated) fisheries.

The splendid alfonsino, Beryx splendens Lowe, 1834 (thereafter alfonsino), is a widely distributed species occurring in North Atlantic (from the Gulf of Maine to the Gulf of Mexico), East Atlantic (from off south-western Europe and the Canary Islands to South Africa), and the Indo-Pacific region (from off East Africa, including Saya de Malha Bank, to Japan, Hawaii, Australia, and New Zealand). The limited number of records in the western Pacific is doubtless a result of limited fishing effort at depths exceeding $200 \mathrm{~m}$. The splendid alfonsino (later in the text referred to as alfonsino) is absent only from the Mediterranean Sea and the north-eastern Pacific (Froese and Pauly 2016). Adult fish inhabit mainly the outer shelf $(180 \mathrm{~m})$ and the slope to the depth of at least $1300 \mathrm{~m}$, occurring mostly between 200 and $600 \mathrm{~m}$; the species is often found above seamounts (Paxton 1999) and underwater ridges (Dubochkin and Kotlyar 1989). The alfonsino is oviparous and spawns in batches (Lehodey et al. 1997). Beryx splendens feed mainly on fish, crustaceans, and cephalopods (Dubochkin and Kotlyar 1989). According to taxonomic studies carried out by Johnson and Patterson (1993), the families Berycidae and Holocentridae and the suborder Trachichthyoidei form a monophyletic group. Extensive information on the beryciforms has been supplied by Kotlâr (1996) who reported the order to consist of 7 families with 29 genera and 144 species. The alfonsino life span is assessed to average several years, the oldest reported specimen being 23 years old (Adachi et al. 2000).

The nature of alfonsino's migrations (unrestricted or spatially constrained) is not known, nor has the gene flow between stocks from various fishing grounds been followed. According to Lévy-Hartmann et al. (2011), the alfonsino shows an extremely high intraspecific diversity, which suggests the presence of genetically separate stocks or even populations. The phylogenetic diversity index (PD50) was estimated at 0.6260 (Faith et al. 2004), which, on the scale of 0.5 (low) to 2.0 (high) indicates a low inter-population diversity, a high diversity being indicated within lower taxonomic groups (stocks or subpopulations).
The annual landings of alfonsino in New Zealand and Korea amount to 2900 and 560 t, respectively; the combined landings in Spain, Chile, and Portugal adding up to about $200 \mathrm{t}$ (Anonymous 2013). The alfonsino fisheries in New Zealand, Australia, and Chile are controlled by catch quota (Bensch et al. 2009). On account of its high meat quality, the species is of a paramount commercial importance and is exported mainly as frozen fish. According to the IUCN threat status established based on comprehensive ecological and biological research, the species falls into the category of 'not evaluated', which also shows that the biology, autecology, and genetics of the species merits study. On the other hand, the intrinsic extinction vulnerability assessment of Cheung et al. (2005) classifies the species as vulnerable. Other sources stress the necessity of determining the intraspecific variability of the alfonsino (Bensch et al. 2009). So far, information on population genetics of this species is scarce, and these result published by Lévy-Hartmann et al. (2011) must be updated. The only data on the cytogenetic index have been provided by Japanese workers (Ojima and Kikuno 1986) and concern the number of chromosomes in diploid cells $(2 n=48)$ and gametes $(n=24)$. In 2006, Chilean scientists who analysed the alfonsino's parasitic fauna found that there most probably exist two non-mixing stocks. However, the amount of available data was regarded as too low for making inferences on the population status (Niklitschek et al. 2007).

\section{MATERIALS AND METHODS}

The presently reported study involved assays made based on fin clips of alfonsino collected in 2012 and 2013 at local markets in Japan (MJ) and New Zealand (MNZ). Prior to transport, the fin fragments acquired in $\mathrm{MJ}(n=$ $10)$ and MNZ $(n=18)$ were dried and placed in $5 \mathrm{~mL}$ vials filled with silica medium. DNA was isolated from the fin fragments with the DNeasy Blood and Tissue Kit (Qiagen) kit, following the manufacturer's instructions. Qualitative and quantitative assessment of the isolates was carried out by separation on $1.5 \%$ agarose gel and spectrophotometric assays using the NanoDrop 2000 (Thermo Scientific). In all the samples, PCR of the nuclear rhodopsin gene (RH1) was carried out using Rod-F2W and Rod-R4n primers according to Sevilla et al. (2007). Subsequently, 16 microsatellite regions (SSR) Orla7-124, Orla16-185, Orla18-49, Orla 9-38, Orla 9-204, Orla 1632 , Orla 2-91, Orla 4-222, Orla 5-131, Orla 3-185, Orla 22-135, Orla 23-61, Orla 8-113, Orla 12-160, Orla 17188, and Orla 20-134 were analysed. Amplification of the regions was carried out as proposed by Gotoh et al. (2013). The only modification to that protocol was the replacement of a standard PCR profile by a touch down PCR: $94^{\circ} \mathrm{C}$ for $5 \mathrm{~min}$, followed by 30 denaturation cycles $\left(94^{\circ} \mathrm{C}, 45\right.$ $\mathrm{s})$, primer annealing $\left(62^{\circ} \mathrm{C}, 30 \mathrm{~s} \times 7\right.$ and $59^{\circ} \mathrm{C}, 30 \mathrm{~s} \times$ $27)$, primer extension $\left(72^{\circ} \mathrm{C}, 20 \mathrm{~s}\right)$, and final elongation $\left(72^{\circ} \mathrm{C}, 7 \mathrm{~min}\right)$. The reaction mixture was prepared with the $12.5 \mu \mathrm{L}$ REDTaq ReadyMix PCR Reaction Mix (Sigma-Aldrich): $0.5 \mu \mathrm{L}$ REDTaq ReadyMix, primer F $\left(10 \mathrm{pmol} \cdot \mu \mathrm{L}^{-1}\right), 0.5 \mu \mathrm{L}$ primer $\mathrm{R}\left(10 \mathrm{pmol} \cdot \mu \mathrm{L}^{-1}\right), 10.5$ 
$\mu \mathrm{L} \mathrm{H}_{2} \mathrm{O}$ DEPC, and $1 \mu \mathrm{L}$ DNA. All the PCRs were run in a GeneAmp ${ }^{\circledR}$ PCR System 9700 (Applied Biosystems) thermocycler. The result of amplification was assessed by separating the amplicons analysed on $2 \%$ agarose gel. The RH1 PCR products were sequenced by Genomed (Warsaw, Poland). The sequences obtained were processed using the BioEdit and BLAST software (Altschul et al. 1990, Hall 1999). The SSR fragments were separated using a SEQ 8000 (Beckman Coulter) sequencer. The SSR data were processed with the GeAlEX software (Peakall and Smouse 2012).

\section{RESULTS}

The BioEdit software-aided comparison of MJ and MNZ nucleotide sequences of the rhodopsingene fragments showed no differences. Subsequently, the $R H 1$ sequences were compared, using the BLAST software, with records deposited in the GenBank. The comparison showed the sequences to agree in $100 \%$ with the alfonsino sequence deposited under access number DQ197832. The preliminary analysis of SSR markers showed all the loci analysed in both populations to be polymorphic, so they were deemed suitable for further analyses. The total number of alleles in the MJ and MNZ populations was 175 and 244, respectively. The number of alleles per locus ranged from 2 to 18 (mean: 10.94) and from 2 to 24 (mean: 15.25) in the MJ and MNZ material, respectively. The allele patterns in both populations are shown in Fig. 1. The observed heterozygosity (Ho), i.e., the ratio between heterozygotic genotypes and the total number of genotypes per locus, was found to range between 0.2 and 1.0 (mean: 0.844) and between 0.056 and 1.0 (mean: 0.837 ) for the MJ and MNZ material, respectively. The genetic diversity $(\mathrm{He})$ was found to range within 0.180 0.935 (mean: 0.829) and within 0.054-0.943 (mean: 0.838 ) for the MJ and MNZ material, respectively (Table 1). No significant deviation from the Hardy-Weinberg equilibrium was found in all the loci analysed in the MJ population and in 14 loci analysed in the MNZ one. It was only the MNZ's Orla 2-91 and Orla 3-151 loci that showed a significant $(P<0.05$ and $P<0.01$, respectively) deviation from the Hardy-Weinberg equilibrium (Table 2). When randomly selected specimens were assigned to the original populations, the affinity test correctly identified the provenance of all those specimens. The test was carried out at the 0.05 significance level (Fig. 2).

\section{DISCUSSION}

Genetic identification of two clades corresponding to populations of the alfonsino caught off Japan and off New Zealand indicates their biological intraspecific separation. Attempts to define the geographic distribution-based structure of the species had been earlier made by Hoarau and Borsa (2000). Having analysed the cytochrome $b$ gene sequence they demonstrated that the species Beryx splendens sensu lato consists of two sub-species, the within-sub-species variation being relatively low. Such genetic homogeneity of lower taxa may be indicative of the absence of gene flow, which in turn is conducive to separation of systematic structures such as stocks, sibling species or ecological species.

The alfonsino is particularly vulnerable to population size reduction by, e.g., overfishing. Catch records of other fish, such as bluenose warehou, Hyperoglyphe antarctica (Carmichael, 1819); silver gemfish, Rexea solandri (Cuvier, 1832); blue grenadier, Macruronus novaezelandiae (Hector, 1871); and thorntooth grenadier, Lepidorhynchus denticulatus Richardson, 1846 contain records of alfonsino individuals as well (Bensch et al. 2009). However, no gear or fishing technique contribution to knocking the alfonsino population off balance has been determined with any precision. As indicated in this paper, research on the

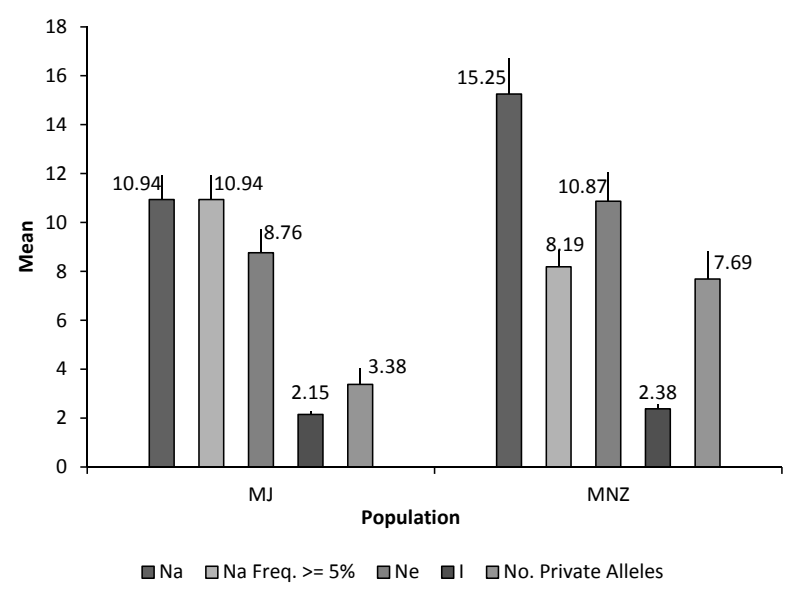

Fig. 1. Distribution of alleles in 16 SSR loci for Japanese (MJ) and New Zealand (MNZ) populations of splendid alfonsino, Beryx splendens; $\mathrm{Na}=$ number of different alleles, $\mathrm{Ne}=$ number of effective alleles, $I=$ Shannon Information Index

Table 1

Mean genetic diversity of the Japanese (MJ) and New Zealand (MNZ) populations of splendid alfonsino, Beryx splendens, as revealed by the analysis of 16 SSR loci

\begin{tabular}{cccccccccc}
\hline Population & $n$ & & $\mathrm{Na}$ & $\mathrm{Ne}$ & \multicolumn{1}{c}{$\mathrm{I}$} & $\mathrm{Ho}$ & $\mathrm{He}$ & $\mathrm{uHe}$ & $F$ \\
\hline MJ & 10 & Mean & 10.938 & 8.763 & 2.147 & 0.844 & 0.829 & 0.872 & -0.020 \\
& & $\mathrm{SE}$ & 1.014 & 0.967 & 0.154 & 0.056 & 0.046 & 0.049 & 0.035 \\
& & & & & & & & & \\
MNZ & \multirow{2}{*}{18} & Mean & 15.250 & 10.867 & 2.375 & 0.837 & 0.838 & 0.862 & 0.002 \\
& & $\mathrm{SE}$ & 1.451 & 1.206 & 0.185 & 0.063 & 0.056 & 0.058 & 0.030 \\
\hline
\end{tabular}

$n=$ number $\mathrm{f}$ specimens studied, $\mathrm{Na}=$ number of different alleles, $\mathrm{Ne}=$ number of effective alleles, $I=$ Shannon Information Index, $\mathrm{Ho}=$ observed heterozygosity, $\mathrm{He}=$ expected heterozygosity, $\mathrm{uHe}=$ unbiased expected heterozygosity, $F$ = fixation index; SE, standard error. 


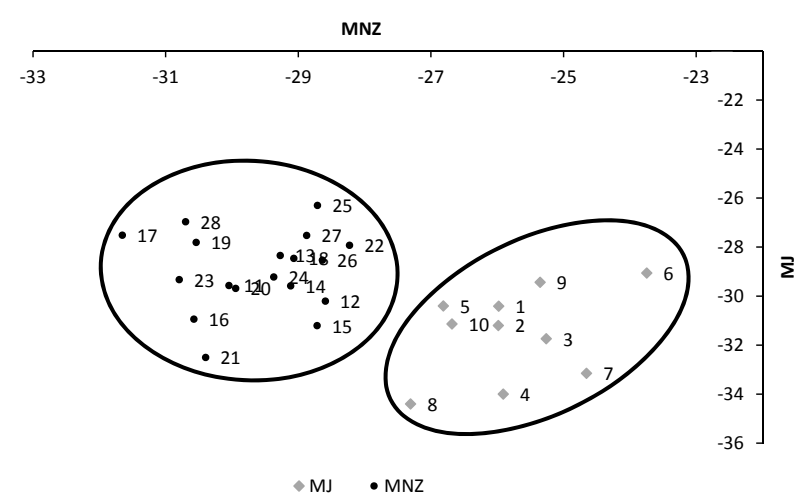

Fig. 2. Genetic distance-based Principal Components Analysis (PCA) of specimens from Japanese (MJ) and New Zealand (MNZ) populations of splendid alfonsino, Beryx splendens

species' genetic status is necessary; such research will make it possible to take measures for developing an alfonsino management plan and for setting catch quota.

Owing to the economic importance of the alfonsino, particularly in New Zealand and in Asian countries, and considering the high meat quality of the species, resources represented by individual populations should be estimated and the populations requiring protective measures should be identified. The problem of genetically homogenous populations does not involve the restriction of the gene pool only and disruption of the Hardy-Weinberg equilibrium. It primarily entails catching of too many juvenile individuals. The market price of the alfonsino meat ranges from NZD 6.50 (whole fish) to NZD 23 (skinless fillet) per kilogram. This is the price range of groupers, snappers, and turbot that was available in 2013 on the pricelist of the Wellington Trawling Company*. In Japan, the whole fish price is JPY 1200 (about USD 10) per kilogram. The profit motive may lead to substituting the species, particularly when sold as half-products, with less expensive fish of a lower nutritive value, e.g., the common warehou, Seriolella brama (Günther, 1860). Genetic markers are being developed to detect such substitutions which mislead consumers by offering them cheaper and less valuable product than that declared on the label. Genetic markers offer a possibility, based on the genome analysis, to authenticate both the species and the capture site of valuable and commercially important fish species. As shown by this study, it is within reach to check whether the fish were caught off Japan or off New Zealand. This in turn makes it possible to identify the provenance of individual batches and, ultimately, will allow revealing how catch quota regulations are observed in those countries where seafood management is not yet perceived as an indispensable component of resource conservation. Subsequently, the approach will make it possible to rebuild the population size and provide a means for controlled exploitation.

\section{ACKNOWLEDGEMENTS}

The presently reported study is the second part of a larger research project carried out within 2011-2014 and entitled "Development of a genetic-based system for identification of food products from fisheries and aquaculture introduced to the European Union customs area". The project was founded by the European Union (Operational Programme "Sustainable Development of the Fisheries Sector and Coastal Fishing Areas 2007-2013" No. 00002-611720-OR1600003/10) and administered by the Agency for Restructuring and Modernisation of

Table 2

Summary of the Chi-square test results for the Hardy-Weinberg equilibrium in Japanese (MJ) and New Zealand (MNZ) populations of splendid alfonsino, Beryx splendens

\begin{tabular}{lcrrrrrrr}
\hline \multicolumn{1}{c}{ Locus } & Population & DF & ChiSq & $P$ & Population & DF & ChiSq & $P$ \\
\hline Orla7-124 & MJ & 66 & 58.889 & 0.720 & MNZ & 153 & 149.000 & 0.576 \\
Orla16-185 & MJ & 28 & 19.556 & 0.880 & MNZ & 45 & 40.306 & 0.671 \\
Orla18-49 & MJ & 153 & 150.000 & 0.553 & MNZ & 276 & 303.000 & 0.127 \\
Orla 9-38 & MJ & 136 & 130.000 & 0.629 & MNZ & 171 & 196.000 & 0.092 \\
Orla 9-204 & MJ & 1 & 0.123 & 0.725 & MNZ & 1 & 0.015 & 0.904 \\
Orla 16-32 & MJ & 55 & 55.000 & 0.475 & MNZ & 91 & 94.160 & 0.389 \\
Orla 2-91 & MJ & 91 & 101.111 & 0.220 & MNZ & 231 & 269.000 & $\mathbf{0 . 0 4 4}$ \\
Orla 4-222 & MJ & 66 & 59.444 & 0.703 & MNZ & 120 & 125.500 & 0.347 \\
Orla 5-131 & MJ & 10 & 14.000 & 0.173 & MNZ & 15 & 32.592 & $\underline{0.005}$ \\
Orla 3-185 & MJ & 91 & 85.556 & 0.641 & MNZ & 190 & 181.500 & 0.659 \\
Orla 22-135 & MJ & 66 & 66.667 & 0.454 & MNZ & 120 & 145.600 & 0.056 \\
Orla 23-61 & MJ & 55 & 58.333 & 0.354 & MNZ & 190 & 219.220 & 0.072 \\
Orla 8-113 & MJ & 36 & 47.500 & 0.095 & MNZ & 66 & 59.786 & 0.692 \\
Orla 12-160 & MJ & 45 & 41.111 & 0.637 & MNZ & 91 & 76.889 & 0.854 \\
Orla 17-188 & MJ & 66 & 75.000 & 0.210 & MNZ & 153 & 168.000 & 0.192 \\
Orla 20-134 & MJ & 28 & 32.667 & 0.248 & MNZ & 78 & 96.469 & 0.077 \\
\hline
\end{tabular}

$\mathrm{DF}=$ degrees of freedom, $\mathrm{ChiSq}=\mathrm{Chi}$-Square statistics; $P=$ probability; Bold font represents $P<0.05$, Underlined value represents $P<0.01$. 
Agriculture (ARiMR, Poland). The project nicknamed CELFISH was carried out under auspices of- and in a close cooperation with the Customs Chamber in Szczecin (Izba Celnaw Szczecinie). In the frames of the CELFISH projects we have hitherto published three papers: DOI: 10.3750/ AIP2014.44.2.08, DOI: 10.3750/AIP2015.45.3.08, and DOI: 10.1016/j.foodchem.2016.11.070).

\section{REFERENCES}

Adachi K., Takagi K., Tanaka E., Yamada S., Kitakado T. 2000. Age and growth of alfonsino Beryx splendens in the waters around the Izu Islands. Fisheries Science 66 (2): 232-240.

DOI: 10.1046/j.1444-2906.2000.00039.x

Altschul S.F., Gish W., Miller W., Myers E.W., Lipman D.J. 1990. Basic local alignment search tool. Journal of Molecular Biology 215 (3): 403-410. DOI: $10.1016 / \mathrm{S} 0022-2836(05) 80360-2$

Anonymous 2013. Capture production 1950-2011. In: FishStat Plus - Universal software for fishery statistics time series. Version 2.32. FAO, Rome, Italy. www.fao. org/fishery/statistics/software/fishstat/en

Bensch A., Gianni M., Gréboval D., Sanders J., Hjort A. 2009. Worldwide review of bottom fisheries in the high seas. FAO Fisheries and Aquaculture Technical Paper No. 522. FAO, Rome.

Cheung W.W.L., Pitcher T.J., Pauly D. 2005. A fuzzy logic expert system to estimate intrinsic extinction vulnerabilities of marine fishes to fishing. Biological Conservation 124 (1): 97-111.

DOI: 10.1016/j.biocon.2005.01.017

Dubochkin A.S., Kotlyar A.N. 1989. On the feeding of alfonsino (Beryx splendens). Journal of Ichthyology 29 (5): 1-8.

Faith D.P., Reid C.A.M., Hunter J. 2004. Integrating phylogenetic diversity, complementarity, and endemism for conservation assessment. Conservation Biology 18 (1): 255-261.

DOI: $10.1111 / \mathrm{j} .1523-1739.2004 .00330 . \mathrm{x}$

Froese R., Pauly D. (eds.) 2016. FishBase. [Version 01/2016] www.fishbase.org

Gotoh R.O., Tamate S., Yokoyama J., Tamate H.B., Hanzawa N. 2013. Characterization of comparative genome-derived simple sequence repeats for acanthopterygian fishes. Molecular Ecology Resources 13 (3): 461-472.

DOI: $10.1111 / 1755-0998.12070$

Hall T.A. 1999. BioEdit: a user-friendly biological sequence alignment editor and analysis program for Windows 95/98/NT. Nucleic Acids Symposium Series 41: 95-98.

Hoarau G., Borsa P. 2000. Extensive gene flow within sibling species in the deep-sea fish Beryx splendens. Comptes Rendus de l'Académie des Sciences - Series III - Sciences de la Vie 323 (3): 315-325.

DOI: $10.1016 / \mathrm{S} 0764-4469(00) 90124-0$
Johnson G.D., Patterson C. 1993. Percomorph phylogeny: A survey of acanthomorphs and a new proposal. Bulletin of Marine Science 52 (1): 554-626.

Johnson R. 2014. Food fraud and "economically motivated adulteration" of food and food ingredients. CRS Report, 7-5700, R43358.

Kotlâr A.N. [Kotlyar A.H.] 1996. Beriksoobraznye ryby Mirovogo okeana. [Beryciform fishes of the World ocean.] VNIRO Publishing, Moscow, Russia. [In Russian.]

Lehodey P., Grandperrin R., Marchal P. 1997. Reproductive biology and ecology of a deep-demersal fish, alfonsino Beryx splendens, over the seamounts off New Caledonia. Marine Biology 128 (1): 17-27. DOI: $10.1007 / \mathrm{s} 002270050064$

Lévy-Hartmann L., Roussel V., Letourneur Y., Sellos D.Y. 2011. Global and New Caledonian patterns of population genetic variation in the deep-sea splendid alfonsino, Beryx splendens, inferred from mtDNA. Genetica 139 (11-12): 1349-1365. DOI: $10.1007 /$ s10709-012-9628-y

Niklitschek E., Cornejo J., Hernández E., Toledo P., Herranz C., Merino R., Lafon A., Castro L., Roa R., Aedo G. 2007. Evaluación hidroacústica de alfonsino y orange roughy, año 2006. Informe final proyecto FIP 2006-09. Universidad Austral de Chile, Centro Trapanada, Coyhaique, Chile.

Ojima Y., Kikuno T. 1986. A heteromorphic chromosome of Beryx splendens, Berycidae (Pisces). Proceedings of the Japan Academy, Ser. B, Physical and Biological Sciences 62 (8): 317-320.

DOI: $10.2183 /$ pjab.62.317

Paxton J.R. 1999. Berycidae. Alfonsinos. Pp. 2218-2220. In: Carpenter K.E., Niem V.H. (eds.) FAO species identification guide for fishery purposes. The living marine resources of the WCP. Vol. 4. Bony fishes part 2 (Mugilidae to Carangidae). FAO, Rome.

Peakall R., Smouse P.E. 2012. GenAlEx 6.5: genetic analysis in Excel. Population genetic software for teaching and research - an update. Bioinformatics 28 (19): 2537-2539.

DOI: 10.1093/bioinformatics/bts460

Sevilla R.G., Diez A., Noren M., Mouchel O., Jerome M., Verrez-Bagnis V., van Pelt H., Favre-Krey L., Krey G., The Fishtrace Consortium, Bautista J.M. 2007. Primers and polymerase chain reaction conditions for DNA barcoding teleost fish based on the mitochondrial cytochrome $b$ and nuclear rhodopsin genes. Molecular Ecology Notes 7 (5): 730-734. DOI: $10.1111 /$ j.1471-8286.2007.01863.x

Received: 10 March 2016 Accepted: 28 October 2016 Published electronically: 31 December 2016 